\title{
FOLK SONG AS AN ADAPTIVE ELEMENT OF SOCIAL CULTURE
}

\section{Poliuha V. V.}

\section{INTRODUCTION}

The contemporary world may be characterised as a world of miscellaneous interethnic contacts that keep expanding and deepening. The geopolitical transformation of social entities, the blurring of the boundaries of cultural restrictiveness and separation of ethnic groups alongside positive consequences also bring about a great number of issues. Scientific researches into social processes lead to the emergence of situations whereby a separate individual, a group, nay even entire national/ethnic entities face a necessity to adapt to a new environment or to adapt their values to it. People find themselves in coexistence of various different communities, diverse cultures, and diverging outlooks thus facing a choice between strategies of social and cultural adaptation.

The pressing nature of the research into the issue of sociocultural adaptation is caused by the following factors: firstly, by objective circumstances determining the condition of the contemporary society; secondly, by the position in which various groups and personalities find themselves in this society; and thirdly, by the significance of ethnic identification that manifests itself in the musical culture which is the most informative variety of spiritual culture. Just as any other kind of art, music is one of the most universal forms of spiritual and practical development and plays an important part in the interethnic communication between people whereas the folk song is a vehicle carrying the "cultural code" of its ethnic group and comprising important characteristics of the national culture. It is a transformation of the system of social traditions, norms and standards, ideals and values.

Addressing the research into the value foundations of the folk song in the formation of the culture of a personality will allow to determine its components, such as: value-based lifelong aspirations, outlook standpoints, and their manifestation in the singing variety of creative activity. These researches are also prompted by the challenges of the our times: the global processes that are making it a crucial matter to ascertain the role played by the creative singing in the adaptive life activities of the human being and of society, by and large. Such researches are, as a rule, of interdisciplinary nature and fall into scientific realms of philosophy, art studies, cultural studies, and sociology. 
The purpose of the work is to outline the criteria of sociocultural adaptation and to ascertain the identity of Slavic peoples in the context of comprehension of their musical traditions specifically, the folk singing. The methodology of this research is determined by gnoseological approach that provides for the revelation of the potential of academic knowledge on a separate segment of socioculture not merely as a realm of cultural and social activity but also as an intention to shift towards the realm of comprehension of its adaptive factor, i.e. the folk song. Academic novelty consists in a brand new view of the research into folk song as an adaptive segment of socioculture among Slavic ethnicities. After all, as of today, one of the most important ways to overcome the spiritual inertia of the personality and the main precondition to its full-blown development as well as the prerequisite for successful socialisation and adaptation to complicated cultural and historical conditions happens to be the folk song as it is one of the most accessible and affordable means with which national and general experience can be put to action. This is why, in this work, we shall examine the issue of sociocultural adaptation of Slavic peoples in the context of comprehension of their musical traditions specifically, the folk song. The process of examination of sociocultural adaptation is taking place in the circumstances whereby independent countries regain their identity and one should take into account the fact that in these countries there is, still, a Russian linguistic and cultural environment whereas the Ukrainian culture in this environment is swiftly growing. That is why the main focus should be on the sociocultural adaptation of the Slavic ethnicities which, in and through their musical traditions, adapt to the existing circumstances of the present day.

\section{Musical Traditions as a Mechanism of Socioculture (psychological, social, and ethnic adaptive components)}

Among the principal directions of our research, we can highlight the following ones: the psychological direction, the social direction, and the ethnic direction. We shall commence with the psychological component of sociocultural adaptation of Slavic peoples, viewing it through the prism of its folk song phenomenon. The multifaceted nature of sociocultural adaptation is conditioned by the existence of differences in the sociocultural, social, and psychological dimensions between the receiving party and the adapting party. Social adaptation in an alien ethnic environment has its external and internal manifestations. If the external character of manifestation reflects the degree to which it is engaged in the social and cultural vital activities of the receiving community and the peculiarities of its interaction with its members, the internal character shall inevitably manifest itself in the psychological and cultural attitudes of the adapting party towards such an environment. In such a 
context, an issue of paramount importance is the communicative function fulfilled by music which manifests itself in the transmission of human vital outlook from the transmitter to the recipient, using coded means of musical art. "It is music that expresses the socially important experience of intellectual and emotional attitude towards events and phenomena the experiencing of one's interaction with the world".

The essential foundations of the sociocultural adaptation consist in their capacity for targeted adaptive activity, in the transformation of oneself and one's environment, in a conscious exchange of activities and information; for that, one also needs to assume a value-based, selective attitude towards the external environment and self-actualisation. The adaptive activity is boosted by personal components linked to emotions, traits of character, will, and temperament. Pursuant to the interactionist theory of varieties of adaptation formulated by L. Phillips ${ }^{2}$, the sociocultural adaptation is conditioned by psychological factors and by the factors of the environment. Slavic peoples show a fast rate of adaptation due to the minimal requirements and expectations of the receiving community.

First and foremost, repatriates accept social norms and successfully adapt to social expectations of the local community which they, due to their age, sex, and profession/occupation, have to get familiar with and hence also to which they have to adequately react (for instance, Catholics congratulate Orthodox Christians on the occasion of the feasts celebrated by the latter they bring treats during the holiday season, sing songs according to the calendar rite principles and thus, friendly relations are established).

Same way, by comprehending the cultural and historical roots of the art of singing, academician N. Uspenskyi notes that the religious tradition "carries culture and enlightenment and ensures the unity of the state" 3 . In this way, sociocultural norms, requirements, and the social order of the other community are being accepted and thus also, elements of the culture of a new ethnic group are introduced into the said community. A new religion brings with it new ideas, a new outlook, a new essence also coded in the musical language. If one also comes to examine the Greek/Byzantine tradition of Christianity, one will see that its outlook is, without any doubt, close to the Slavic culture of singing particularly as far as the narrow range of melodies, the lax rhythm of chanting, and diatonicism are concerned. The establishment

\footnotetext{
${ }^{1}$ Bermes, Iryna: Ukrayinskyi khorovyi spiv yak sotsiokulturne yavyshche/Ukrainian Choral Singing as a Sociocultural Phenomenon. Drohobych: Posvit Publishing House, 2013. Page 64.

${ }_{2}$ Philips, L.: Human adaptation and his failures. N-Y\&London: Academic Press, 1968. Page 294.

${ }^{3}$ Uspenskyi, N.: Drevnerusskoye pevcheskoye iskusstvo/The Art of Singing of the Old Rus. Moscow: Sovietskii kompozitor Publishing House, 1971. Page 619.
} 
of the ecclesiastical choir art in the Kyivan Rus has found its reflection in academic works and researches conducted by scientists who have put forward a range of hypotheses on the matter of musical intentions of Byzantine Empire and the Kyivan Rus. These have been systematised by Iryna Bermes: "1) the influence of the Byzantine culture upon the musical environment of was the consequence of the adoption of Christianity (V. Metallov, D. Rozumovskyi); 2) professional choral singing derived from Bulgaria and then Slavified (O. Kartashov, I. Gardner); 3) formation of stylistics of choral church singing by way of synthesis of intonation means of various ethnic traditions of Christian liturgy (Byzantine, Roman, Armenian) as well as sources of one's own folk creativity, the music of Slavic pagan cults (M. Hrushevskyi, S. Kylymnyk); 4) influence of musical and performance cultures upon Transcaucasian countries (P. Matsenko); 5) influence of Western vocal art (M. Findeizen, I. Gardner)"

This process is not a mere acceptance of sociocultural norms but a search for flexible and the most acceptable ways to adapt to new vital circumstances which, actually, helps to streamline the process of adaptation in the required direction. This very thing reveals the essence of efficient adaptation, as it contains the idea of targeted and transformative activity of a personality.

We can therefore assert that, in the process of adaptation, Slavic peoples do not evade sociocultural contacts but instead adapt their behavioural patterns in order to navigate the brand new system of social and cultural values more efficiently. It is also worth noting that the following psychological elements stand out particularly distinctively: vital orientations, value-based aspirations, dynamics of behaviour, sociocultural preferences and instruments of cultural exchange that are focused on a certain model of social behaviour. In culture, a social imitation is manifested through the "memory" of humanity and subjectivises itself in certain systems of symbols in our case, in the art of music. Here, social experience of the preceding generations is desubjectivised, 'decoded', and is accepted by new generations. One of the mechanisms of this process is the musical tradition which preserves the code of the nation in folk songs.

Formation of adaptive behaviour depends on how do repatriates appreciate their cultural situation, as well as on which instruments are used to ensure sociocultural survival of oneself and one's nearest environment in the social system of values. Within the framework of this statement, it would be acceptable to assume the approach stipulated by L.L. Shpak who presents/construes sociocultural adaptation as a "manner of mutual adaptation

${ }^{4}$ Bermes, I.: Ukrayinskyi khorovyi spiv yak sotsiokulturne yavyshche/Ukrainian Choral Singing as a Sociocultural Phenomenon. Drohobych: Posvit Publishing House, 2013. Page 98. 
of subjects and sociocultural environment on the basis of exchange of spiritual and practical possibilities and results of activities in certain specific adaptive situations" $"$.

Likewise, sociocultural adaptation is dominated by spiritual and practical efforts which are of value and orientation significance and which serve to put the adaptive potential into action. Thus, one can assert that the psychological content of sociocultural adaptation of the Slavic peoples consists in the potential and the striving to internalise habits, musical traditions, and vital cultural activities of the receiving population, whereas the peculiarities of musical traditions serve as a basis for the transfer of religion into the realm of individuality and internal adaptation.

One important component of sociocultural adaptation is the fact that this process is a social process. A social process of any kind is a phenomenon that is characterised by a certain duration over time, by sequence wherewith all of the previous stages and states/conditions impact all of the subsequent ones. Sociocultural adaptation is likewise stretched over time, is uninterrupted, successive/concurrent, and each of its stages are distinctively marked as each subsequent stage is built upon the preceding one. As per P.O. Sorokin, a "social process" is construed as 'any kind of movement, modification, transformation, alternation or evolution in other words, any dimension wherein we observe the object in question, viewed over time, be it in the context of its relocation in space or in the context of the modification of its quantitative and qualitative characteristics ${ }^{\prime 6}$. It is therefore necessary to underline the fact that the process of sociocultural adaptation is characterised as cumulative interaction of people reflecting a certain tendency towards change or preservation of the social conditions for their group as well as preservation of the conditions wherein each of the member of their own group, as a personality, is able to reproduce and develop. The sociocultural adaptation of repatriates is a reflection of the characteristics of the social processes that unfold in the society and impact the transformation of the community's sociocultural essence and the modification of its qualitative characteristics. Peculiarities of sociocultural adaptation as a social process include a certain transformation of an ethnic group over a certain time. In the process of sociocultural adaptation, certain groups of Slavs have experienced certain changes in their outlook, ethnic traits, in the manner of social and intergenerational interaction, in the attitude towards traditional cultural values.

5 Shpak, L.: Sotsiokulturnaya adaptatsiya/Sociocultural Adaptation: sushchnost, napravleniye, mekhanizmy realizatsiyi/essence, direction, and mechanisms of implementation: thesis of PhD in Sociological Sciences. Kemerovo City, Russia, 1992, Page 106.

${ }^{6}$ Sorokin, P.A.: Chelovek, tsivilizatsiya, obshchestvo/Man, Civilisation, Society. Moscow: Politizdat Publishing House, 1992. Page 210. 
This is reflected in the musical culture of Slavic nations which gave birth to folk singing a form of art most in line with national mindset. Slavs in particular tend to prefer vocal and choir-based genres of music and arts that is, folk singing and Christian church music. All of the above traces back to the heyday of church monody (the $9^{\text {th }}$ century) that has swiftly evolutionised in the Eastern Slavic lands. By $15^{\text {th }} / 16^{\text {th }}$ century, an ethnoregional bifurcation into two branches has already been in place: the Ukrainian and Belarussian branch on the one hand and the Russian (Muscovite) branch on the other hand both having certain common roots but each having developed its respective ethnic variants. This is confirmed by the comparison of chants and manuscripts of Ukrainian, Russian, and Belarussian origin: the Ukrainian/Belarussian monody had already been developed by the late $16^{\text {th }}$ century.

Another trait characterising the process of sociocultural adaptation consists in its ethnic nature and is correlated with the specifics of functioning of the ethnic self-awareness the notion and structure of which comprises not only ethnical identity but also the ideas people have about the traits characteristic to their ethnic group (the "ethnic auto-stereotypes"), about its origin, historical past, traditions, norms of behaviour, customs, as well as ideas about the territory they populate and the culture their ethnic group cherishes. This also includes language which being one of the definitive marks of ethnicity is construed as a general mark of the ethnic group. At the same time, the ethnic cognition is particularly sensitive in its reactions to sociocultural changes. A renaissance of such identification is impacted by fundamental aspects of ethnicity, such as: language, history, culture, self-designation (endonym), ethnic etiquette, religion, musical culture etc. At the same time, on various levels of ethnic renaissance including the level of subconsciousness particularly influential is the system of values wherein the experience and information of the previous generations has been taken into account. A showcase example of the above is the musical folklore of Slavic peoples which, in the opinion of A. Ivanytskyi, “... have absorbed the aesthetic, moral, legal, and outlook experience of hundreds of generations" "T. The musical folklore is developing concentrically - it is "the wisdom and the tradition-based legal system of the people"s.

One of the criteria of sociocultural adaptation is whether one does or does not realise that one belongs to one's motherland/fatherland and not to some other territory. The ethnic self-awareness is manifested in the fact that these people do indeed recognise themselves as Slavs. The shaping of ethnic identity is related to the self-affirmation, with pride, with positive appraisal

\footnotetext{
${ }^{7}$ Ivanytskyi, A.: Ukrayinska narodna muzychna tworchist/Ukrainian Folk Music Art. Kyiv: Muzychna Ukrayina Publishing House, 1990. Page 5.

${ }^{8}$ Shaian, V: Vira nashykh predkiv/The Faith of Our Ancestors. Hamilton, ON, 1987. Page 616.
} 
and is also linked to behaving in a certain way that is acceptable, normal, and common in their culture, and accepting a certain system of values. Thus, these people come to recognise this territory as their own land and come to view others as aliens, viewing their culture and traditions as phenomena that were created in this particular land. Such an outlook also complies with a substantialistic statement on the nature of ethnic identity that is revealed in the "ideas maintained by people on the matter of their ethnic origin, on the matter of how they belong in their own land, and on the internalised ideas on the matter of the historical past and present, as well as on the matter of their

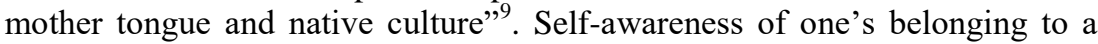
country or a community inevitably means that one is aware of one's ethnic group's endonym (self-designation). An ethnic group may have several names: one might be their endonym and the other names might be the names given to that ethnic group by other ethnicities. Ethnic self-awareness cannot exist without an endonym. If the members of a certain cultural/linguistic community do not have an ethnic self-awareness, such group shall not be regarded as an ethnos (ethnic group). Principal ethnic groups that used to inhabit the present-day Slavic territories in the past include: Tauri, Scythians, Sarmatians, Alans, Greeks, Goths, Romans, Proto-Bulgars, Khazars, Pechenegs, Italians, Circassians, Asia Minor Turks, and turkified Mongol tribes. That is why, residing in an alien ethnic environment inevitably leads to acquisition of the cultural values of the receiving society, to the adoption of hitherto alien and strange culture, and to a gradual drift away from one's own "home" culture. This long-lasting process gradually leads to a cultural assimilation, to ethnic absorption or dissolution and may end in a change in self-awareness as far as ethnic self-identification is concerned. It should be noted, though, that the bicultural character of self-awareness and selfidentification may play a positive role (as one preserves one's own culture) as well as a negative role (as one self-marginalises thereby) in the process of alleviation of the cultural shock and maintenance of positive selfidentification. In order to ascertain this, we really should address the peculiarities of the concepts of "cultural shock", as stipulated by K. Oberg ${ }^{10}$ and "acculturation" as stipulated by J. Berry ${ }^{11}$, within the framework of which the successful adaptation is determined by two categories undergoing that adaptation: the passive ones that accept the norms and the values of the Slavic

9 Khabibullin, K.N.: Natsionalnoye samosoznaniye $i$ internatsionalistskoye povedeniye/National Self-Awareness and Internationalist Behaviour. Leningrad, 1989. Page 7.

${ }^{10}$ Lebedeva, N.M.: Vvedeniye v etnicheskuyu i kross-kulturnuyu psikhologiyu/Intro to Ethnic and Cross-Cultural Psychology: ucheb. posobiye/A Textbook. Moscow: Klyuch Publishing House, 1999. Page 193.

${ }^{11}$ Berry, J.W. Immigration, acculturation and adaptation, Applied Psychology, No. 1. January. V. 46, 1997. Page 30. 
majority and the active ones that bring the innovations from their own culture to the table and do not waive their own cultural traditions and customs. In the behaviour of passive adaptants, we may observe frustration, marginalisation, a change in the system of values and acceptable norms, and assimilation. Indicators of adaptation among active adaptants include: the extensive usage of one's native/mother tongue, corrections in one's traditions and customs, high "density" of contacts, establishment of positive connections with the local population, satisfaction of social and cultural requirements, as well as psychological satisfaction with the conditions in which one's environment (as a whole) resides. That said, both categories of adaptants manifest signs of successful adaptations as both establish positive contacts and use the behavioural patterns that fit and are appropriate for the normative requirements. This has become an indicator of the process whereby mechanisms of social engagement and consistent patterns in the interaction of cultures have developed particularly in the Ukrainian-Belarussian-Russian triangle of cultures.

On the basis of what was stated above, it should be noted that the sociocultural adaptation develops alongside the trajectory of expansion of the interconnections and interdependence between different nations inhabiting the same territory. This process has impacted various realms of civic, social, and cultural life and it is all but impossible to find aspects that would not have been impacted by the cultures of other nations, and the other way round.

\section{The Phenomenon of Folk Song in Socioculture (a Philosophical Discourse)}

Socioculture construed as a complex, multifaceted notion constitutes a synthesis of relations and culture, a manifestation of social essence of culture. The Socioculture presents itself as a systemic quality comprising spiritual values, folk traditions, social experience, regulations, rules, and norms of behaviour. Socioculture reflects the extent of one's command of one's own cultural heritage specifically, its imitation and usage in the social activity of a certain separate individual and of a specific separate social/ethnic group and its respective society in general. An in-depth analysis of the components of the notion of "socioculture" that is, "socium" (social medium) and "culture" has been conducted in a paper entitled "Culture. Society. Civilisation" put together by Pytyrym Oleksandrovych Sorokin (1889-1968), a renowned sociologist, culturologist, and the founder of the theory of social mobility. Sorokin notes that: "The sociocultural structure is integral and no one is able to design a custom-purpose science on the basis of a sole aspect for instance, on the basis of social aspect and ignore the culture and personality-related 
aspects at the same time" 12 . He goes on by explaining that "... each organised group does necessarily have a command of the norms and regulations of law and morality. The legal and moral values are a significant part of the cultural values. That is why, any organised group will inevitably have a command of culture. Moreover, neither the social group nor an individual (apart from those "individuals" who have nothing 'on top of' their biological organisms) cannot exist without the components of meanings and carriers/vehicles that is, they cannot exist without a culture. This is precisely why the "society" cannot be described using a term that would be broader than the term of "culture" as both of these phenomena cannot be viewed and examined separately from each other" ${ }^{\prime 3}$. Therefore, socioculture is not merely a culture but a process of activity of a separate human being wherein there is a reflection of the social elements. Thanks to culture and through the culture, social elements reflect themselves. That is why, for a more substantial realisation of the subject problematics, we shall address the definition of an element of the Socioculture that is, culture.

Viewed in the philosophical aspect, culture may be construed as a realm of semantic existence of a human being, the realm of senses, meanings, and values. "Culture is likewise a peculiar way of human cognition and creation. Construed thereby, it may be interpreted as a process of creation and reproduction of life in the eternity pursuant to the laws of the supreme senses of Verity, Goodness, and Beauty... and this triad of human life (VerityGoodness-Beauty) manifests itself in the following principal realms of spiritual practice: religion, science, philosophy, morality, law, and arts. That is why, when culture of a certain ethnic group is examined, the examination comprises the achievements of that particular ethnic group in the realms of religion, science, philosophy, morality, law, education, and arts (including plastic art/sculpture, architecture, fine art painting, musical art, poetry, the art of dancing and suchlike)"14. The notion of culture, in its essence, comprises the social element. Culture is a "symbolic universum" of socium, of its norms, behavioural patterns, traditions, material artefacts, and so on. Considering the fact that culture is a creative activity, a realm of human life that is filled with a value-based meaning wherein human existence is filled with a quest for truth (or verity), with an ascertainment of virtues, with beauty filling the world, we

${ }^{12}$ Sorokin, P.A.: Chelovek, tsivilizatsiya, obshchestvo/Man, Civilisation, Society. Moscow: Politizdat Publishing House, 1992. Page 171.

${ }^{13}$ Ibid: Page 172.

${ }^{14}$ Yaroshenko, T.M.: Fenomen ukrayinskoyi kultury / The Phenomenon of the Ukrainian Culture. Dzherelna baza ta metodologichni zasady yiyi vyvchennia / The Bibliographical Basis and Methodological Foundations for a Study into it. Istoriya ukrayinskoyi kultury / The History of Ukrainian Culture (a journal), Lviv: Lviv Ivan Franko National University 2012. Page 11. 
may assert that the anthropological approach to the definition of the in-depth sense of 'culture' stresses the importance of the role played by the subjective factor of human being in the history and culture and appears to be the answer to the question of who is the actual creator of history and culture. A cultured human being is a creative personality: he or she has a command of intellectual capacities and abilities; is developing the intellectual prerequisites and capabilities; recognises the moral will to live; and is characterised by peculiar artistic preferences and taste. Such a human being is a vehicle, a creator, and a subject of and with respect to culture.

As we can see, an important place is occupied by the comprehension of the creative fount in the human being-which, in our research, is focused on the research into the phenomenon in question: the folk song. Contemporary academic thought dedicates ample attention to the research into the issues of folk song as a creative act in the sociocultural context. "The phenomenon of the folk song is interpreted as a form of activity carrying the foundations of the life of the human being-and also of the nation group to which that human being belongs. The philosophical comprehension of this notion foresees its connection with the social development of human beings, their creative forces, and their capacities" ${ }^{\prime 15}$. After all, creativity is a form of activity that is giving birth to something that is qualitatively brand new-something that had never existed before. Taking into consideration the context of the research, the present phenomenon is being comprehended in the context of harmonised feeling of "communion" with phenomena and cultural events. The creative act that lies in the foundation of the folk song may be interpreted as one of the forms of human self-actualisation, self-development, and self-expression. Moreover, the folk song also arises as a creative ability of the human being to create new reality or, as a process of comprehension of the world within the process of artistic intuition. "The art of singing, construed in its present interpretation, may be showcased as the most important instrument used to overcome the spiritual inertia of the personality; as one of the most important-preconditions for a comprehensive human development; as a prerequisite to enculturation, socialisation, and adaptation to the cultural and historical circumstances"16. It is

\footnotetext{
${ }^{15}$ Chaplyhin, O.K.: Tworchyi potentsial lyudyny/The Creative Potential of the Human Being: vid stanowlennia do realizatsiyi (Sotsialno-filosofskyi analiz)/ from Establishment to Implementation (a Social and Philosophical Analysis). Kharkiv: Osnova Publishing House, 1999. Page 72.

16 Popova, L.M.: Pesennoye tvorchestvo kak aspekt filosofsko-kulturologicheskogo znaniya/The Art of Singing as an Aspect of Philosophical and Culturological Knowledge. Kultura/Culture: opyt, problemy, issledovaniya i prepodavaniya gumanitarnykh nauk/Experience, Problems, Research Studies, and Teaching of Humanities: Belgorod: Belgorod State Institute of Arts and Culture, 2011. Page 275.
} 
this particular form of art that has organically absorbed the knowledge that plays a paramount role in the process of formation of the culture of a personality. In order to comprehend the art of folk singing, we should examine it as a special form of activity that is internalising the personality-based potential properties and resources. "Being a certain specific variety of human activity and thinking, the art of folk singing has been organically embedded in the process of material and spiritual life of human beings for a long-long tim-more than other forms of art"17. This variety of art had its own purpose and was implementing the aspirations and interests of society, presenting itself as a vivid embodiment of philosophical, religious, ethical, and mindset-based peculiarities and of national/ethnic self-awareness of a certain era. "The folk singing has immensely impacted the spiritual world of human beings and their interaction with society and has contributed to the formation of an adequate comprehension of socium, of moral stances, of positive attitude towards national traditions and towards general humanist values" ${ }^{\text {18 }}$. By addressing the phenomenon in question that is being researched by us, we shall inevitably likewise address the comprehension of social values. Any kind of society, in its basis, possesses a certain system of values that is adequate with respect to its needs and interests. The phenomenon of folk song, construed in general terms, consists in the compliance of a certain object with the interests of society. "Objects giving birth to a value-based attitude may include objects from the natural world, products of human social activity, interpersonal and social relations, norms of behaviour and various expressions of creative spirit" ${ }^{\prime 19}$. Value-based attitudes are shaped under the influence of miscellaneous sociocultural factors. The latter, as a rule, are not constant variables-therefore, even the attitude towards absolute values undergoes change over time. Today, the art of folk singing should be examined through the prism of value-based dimension as this form of art presents itself in the context of ethnic and national identity. "Contemporary processes of globalisation blur the self-identification and self-awareness of nations, erasing borders between them; globalisation carries with it threats that are related to the existence of cultural diversity of nations, ethnic groups, cultures, and

17 Shynkaruk, V.I.: Poniattia kultury / The Notion of Culture. Filosofski aspekty/The Philosophical Aspects. Fenomen ukrayinskoyi kultury / The Phenomenon of the Ukrainian Culture: Metodologichni zasady osmyslennia / The Methodological Foundations for Comprehension. Kyiv: Feniks Publishing House, 1996. Page 11

18 Shynkaruk, V.I.: Poniattia kultury/The Notion of Culture. Filosofski aspekty/The Philosophical Aspects. Fenomen ukrayinskoyi kultury / The Phenomenon of the Ukrainian Culture: Metodologichni zasady osmyslennia / The Methodological Foundations for Comprehension. Kyiv: Feniks Publishing House, 1996. Page 11.

${ }^{19}$ Kagan, M.S. : Filosofskaya teoriya tsennostey / The Philosophical Theory of Values. Lektsiyu / Lectures. Saint Petersburg: TOO TK Petropolis Publishing, 1997. Page 109. 
communities" 20 . In this context, "the art of folk singing is a syncretic form of art wherein the artistic processes are in conjunction with other forms of social awareness, reflecting the reality in the course of its development" ${ }^{\prime 21}$. Forms of social awareness that are engaged in this process constitute a pretty large group including folk traditions, rites, customs, religious beliefs - and, of course, the folk singing. The complexity of the art of singing which is a phenomenon of folk existence is ascertained by the multitude of functions fulfilled by it. These functions include: social, educative, cognitive, communicative, aesthetic and other functions. This enumeration provides grounds to assert that, in many cases, folk singing has presented itself as a unique sociocultural phenomenon. The abovementioned justifies our assertion that the phenomenon of folk singing constitutes an integral element of personality-based, cultural, and social life that is reflecting the integrity of outlook, comprehension and perception of the outer world. Such comprehension allows us to register any stage of cultural and historical existence of human beings and society as a whole at any time, using the so-called "binary verbal concepts: the word and the sound", that are shaping the outlook of human beings, their aesthetic, moral, spiritual, and artistic realms of activity ${ }^{22}$.

Examining the art of singing as a complex process of spiritual and material constructions, researcher L. Popova asserts that, in terms of their nature, this form of art is polyfunctional. "One of its important functions is the philosophical/culturological function: on the basis of it, the ethnic selfawareness is being formed as a component of the planetary conscience, assisting in threats arising out of narrow nationalistic thinking, negative prejudices and stereotypes with respect to representatives of other ethnic entities and their respective cultures" ${ }^{23}$. All of the other functions, including

\footnotetext{
${ }^{20}$ Herchanivska, P.E.: Funktsionuvannia narodnoyi kultury $v$ sotsiumi/The Functioning of the Folk Culture in the Socium. Kultura Ukrayiny / The Culture of Ukraine. Issue 29, 2010. Page 133.

21 Zhyrov, M.S., Popova L.M.: Kulturoobrazuyushchiye osnovaniya pesennogo tvorchestva/The Culture-Shaping Foundations of the Creative Art of Singing. Nauchnyie vedomosti Belgorodskogo gosudarstvennogo universiteta/Academic Journal of Belgorod State University. Seriya/Series' Filosofiya/Philosophy. Sotsiologiya/Sociology. Pravo/Law', No. 20 (115), Issue 18, Belgorod, 2012. Page 29.

${ }_{22}$ Zhyrov, M.S., Selyukova T.A. : Narodnoye muzykalnoye tvorchestvo kak filosofskokulturologicheskaya kategoriya / The Folk Art of Music as a Philosophical and Culturological Category. Nauchnyie vedomosti Belgorodskogo gosudarstvennogo universiteta/Academic Journal of Belgorod State University. Seriya/Series 'Filosofiya/Philosophy. Sotsiologiya/Sociology. Pravo/Law", No. 2 (97), Issue 15, Belgorod, 2011. Page 218.

23 Zhyrov, M.S., Popova L.M.: Kulturoobrazuyushchiye osnovaniya pesennogo tvorchestva/The Culture-Shaping Foundations of the Creative Art of Singing. Nauchnyie vedomosti Belgorodskogo gosudarstvennogo universiteta/Academic Journal of Belgorod State University. Seriya/Series 'Filosofiya/Philosophy. Sotsiologiya/Sociology. Pravo/Law', No. 20 (115), Issue 18, Belgorod, 2012. Page 289.
} 
ethical/humanist, humanitarian, educative/reflexive, personality development function, cultural and communicative function and other functions represent the complexity and multitude of variants of the sociocultural phenomenon that we are researching. Considering the peculiarities of the folk song as a unique manner of preservation of Ukrainian culture that is encompassing the human will, the human intelligence and human outlook, we should note that the formation of this culture is the task fulfilled by the culture of thinking and perception of the outer world. "The role played by creative folk art in the shaping of the foundations of the outlook can hardly be overestimated since this art, being embedded in the system of basic moral values, norms, and artistic images, presents itself as a cornerstone component" ${ }^{, 24}$. That is why the creative folk art, in addition to the functions enumerated above, also includes the function of preservation of values and outlook, as not only does it integrate the human being within the world but also includes the human being in its system of values. The human being that either sings a folk song or listens to it, therefore, cherishes and fosters his or her striving for and ability to introduce the elements of the beautiful and the aesthetic phenomena into all walks of life: everyday household life, work, social interactions, and social activity that is, a human being gets ready to efficiently engage in creative activities. "A folk song, being a transmitter of spiritual values (Verity, Kindness, Goodness, Beauty, Love, Sanctity), deep senses that are embedded in her and in the world around her, helps the human being to immerse in the mystery of human destiny, to comprehend the meaning of one's own existence, to become a spiritually unique component of global fabric" ${ }^{25}$. Folk song is a phenomenon that goes beyond the framework of common juxtapositions of the internal and the external world, of the material world versus the spiritual world, it executes the "spiritual orientation" of the human being, of society, and of humanity, by and large. It is precisely due to the creative folk singing art which is a unique form of transmission of ancestral, national, ethnic, and historical memory that it comes to be feasible to retain and preserve the spiritual culture of the human being and the culture of his or her folk, ethnic group or nation. Thus, on the basis of all of the arguments stated above, we may state that the folk song may be presented as a sort of a

${ }^{24}$ Pastushenko, A.S., Ponomarenko M.I.: Narodna pisenna tworchist $v$ Ukrayini/The Creative Art of Folk Singing in Ukraine: navch. posib./guidebook. Rivne : PPDM, 2011. Page 10.

25 Zhyrov, M.S., Popova L.M. : Kulturoobrazuyushchiye osnovaniya pesennogo tvorchestva/The Culture-Shaping Foundations of the Creative Art of Singing. Nauchnyie vedomosti Belgorodskogo gosudarstvennogo universiteta/Academic Journal of Belgorod State University. Seriya/Series 'Filosofiya/Philosophy. Sotsiologiya/Sociology. Pravo/Law', No. 20 (115), Issue 18, Belgorod, 2012. Page 291. 
sociocultural phenomenon and as an instrument allowing to preserve national traditions, national and ethnic experience and self-awareness. At the same time, the phenomenon of the folk song also presents as an expression of certain aesthetic, sociocultural, philosophical, and moral labels that distinctively characterise its overall social and ethnic image. We should note that the key element in this research is based upon the idea of phenomenon of the folk song that is one of the basic factors of adaptation and shaping of the identity and development of the human culture.

\section{CONCLUSIONS}

Having analysed the abovementioned aspects and criteria of sociocultural adaptation through the prism of folk song, it is our opinion that this process is an adaptation of an ethnic group to new conditions and circumstances that have arisen, whereas considering the corresponding sequence of incomplete and overlapping adapting states, it may be concluded that this process may not be construed as a finalised process and may not be interpreted as a process that has been completed. This is a pending process whereby the ethnic group finds itself integrated into new forms, conditions, circumstances, interactions within human activities, as an element that is integral and essential to the life of the people, ethnic group, and nation, because its vital environment (including physical, mental, social, information, and cultural components) can never be entirely static; it is incessantly developing, changing, and combining into new patterns. Thus, the musical culture of the Slavic peoples as it has undergone an extensive development over a significant amount of time has experienced constant enrichment with achievements and traditions of separate ethnicities but has, at the same time, presented itself in its uniqueness which (in different historical periods) was being expressed in different manners. That said, each ethnic group and each nation possess a certain uniqueness and it is this very uniqueness that manifests itself through and in music. Owing to the above, there exists a multiethnic world of music that is a common spiritual treasury.

Therefore, it may be asserted that sociocultural adaptation is taking place through spiritual and practical activity the main essence of which is the adaptation and acclimatisation to the material culture, to its norms, values, patterns of behaviour of the new environment as well as through selftransformation and the transformation of this environment in accordance with the needs and demands of the parties engaged in mutual interaction. Adaptation of Slavs does not resemble generic process of migrants adaptation; it consists in the fact that they adapt to the environment with a population sharing common outlook and mindset of a certain era, despite the fact that the receiving population and the receiving environment may be the vehicles of 
other ethnic traditions and customs. By finalising the selection and the accumulation of the social experience and by impacting the processes of socialisation, the folk song reflects the shaping of human being engaged in culture. The abovementioned also prompts us to reconsider and reinterpret the significance of the phenomenon in question from the standpoint of human vs creative folk art singing which becomes increasingly open and influential whereas the sociocultural environment that is preserving and ensuring mutual penetration of the folk song in the process of adaptation presents itself as the social world that surrounds them encompassing the cumulative amount of personality-based elements that impact their activity as far as the renaissance of one's own values and exploring of other values is concerned.

To conclude, we should stress the importance of the factors of sociocultural integration, communication, and adaptation. The awareness of the importance of their role arises out of the understanding of the fact that the culture of each nation and ethnic group is not being developed in isolation from the other cultures but is indeed related to the processes of human migration and hence also related to the interaction of the humans' respective cultures and with the exchange of values and experiences. Peoples and ethnicities that inhabit a certain geographical area establish certain economic, political, nay even spiritual contacts and connections between each other and develop common rules of life and similar customs, traditions, and values. All of the above leads to the formation of similar traits in their cultures and all of the above allows us to examine broader regional types of communities and their respective cultures. This is of particularly important for the present-day humans, their societies and cultures in the era of globalisation.

\section{SUMMARY}

The objective of the article is to separate and outline the criteria of sociocultural adaptation and to ascertain the identity of Slavic peoples in the context of examination and appraisal of their musical traditions-specifically, the art of creative folk singing. Methodology of the research is based upon the gnoseological approach which stipulates the revelation of the potential of academic knowledge on the subject of a separate element of socioculture not only as a realm of cultural and social activity but also as an intention to move towards the realm of knowing its adaptive factor: the folk song. Academic novelty consists in the brand new view of the research into folk song that is construed as an adaptive segment of socioculture in Slavic ethnicities. Conclusions state that the adaptive segment constitutes an adaptation of the ethnic group to new social and cultural conditions and circumstances and is in fact a corresponding sequence of incomplete, overlapping adaptive states hence, the process in question may not be construed as a 'result' and may not 
be regarded as a process that has reached its completion. The sociocultural environment, with its retention, preservation, and mutual penetration of elements via folk song in the process of adaptation presents itself as a social world that surrounds them and comprises the cumulative amount of personality-based elements that impact the activity aiming at renaissance of one's own values and exploration of the values of others. We should note that the key element in this research is based upon the comprehension of the phenomenon of the folk song that is one of the basic factors of adaptation and shaping of the identity and development of the human culture. By finalising the selection and the accumulation of the social experience and by impacting the processes of socialisation, the folk song reflects the shaping of human being engaged in a certain culture.

\section{REFERENCES}

1. Бермес, I.: Украӥнський хоровий спів як соиіокультурне явище. Дрогобич: Посвіт, 2013. 432 с.

2. Герчанівська, П.Е.: Функціонування народної культури в соиіумі. Культура України, Вип. 29, 2010. С. 132-141.

3. Жиров, М.С., Попова Л.М.: Культурообразующчие основания песенного творчества. Научные ведомости Белгородского государственного университета. Серия “Философия. Социология. Право”, № 20 (115), Вып. 18, Белгород, 2012. С. 287-294.

4. Жиров, М. С., Селюкова Т. А.: Народное музыкальное творчество как фылософско-культурологическая категория. Научные ведомости Белгородского государственного университета. Серия “Философия. Социология. Право”, № 2 (97), Вып. 15, Белгород, 2011. С. 213-224.

5. Іваницький, А.: Украйнська народна музична творчість. К.: Музична Україна, 1990. С. 5.

6. Каган, М.С.: Философская теория иенностей. Лекиии. СанктПетербург: ТОО ТК Петрополис, 1997, 205 с.

7. Культурологічний словник / за ред. В.І. Рожка. Київ : НМАУ, 2011. $464 \mathrm{c}$.

8. Лебедева, Н.М.: Введение в этническую и кросс-культурную психологию: учеб. пособие. М.: Ключ, 1999. С. 193.

9. Пастушенко, А.С., Пономаренко М. І.: Народна пісенна творчість в Украйні: навч. посіб. Рівне : ППДМ, 2011. 303 с.

10. Попова, Л. М.: Песенное творчество как аспект философскокультурологического знания. Культура: опыт, проблемы, исследования и преподавания гуманитарных наук: Белгород: БГИКИ, 2011. С. 272-276.

11. Сорокин, П.А.: Человек, цивилизация, общество. М.: Политиздат, 1992. $543 \mathrm{c}$. 
12. Успенський, Н.: Древнерусское певческое искусство. М.: Советский композитор, 1971. С. 619.

13. Хабибуллин, К.Н.: Национальное самосознание и интернаџионалистское поведение. Л., 1989. С. 7.

14. Чаплигін, О.К.: Творчий потенщіал людини: від становлення до реалізачї (Соціально філософський аналіз). Харків : Основа, 1999, 277 с.

15. Шаян, В.: Віра наших предків. Гамільтон, 1987. С. 616.

16. Шинкарук, B.I.: Поняття культури. Філософські аспекти. Феномен украинської культури: Методологічні засади осмислення. Київ : Фенікс, 1996. С. 8-16.

17. Шпак, Л.: Социокультурная адаптащия: сущчность, направление, механизмы реализации: дис. д-ра социол. наук. Кемерово, 1992. С. 106.

18. Ярошенко, Т.М.: Феномен української культури. Джерельна база та методологічні засади ї̈ вивчення. Історія української культури, Львів: ЛНУ імені І. Франка, 2012. С. 11-45.

19. Philips, L.: Human adaptation and his failures. N-Y\&London: Academic Press, 1968. C. 294.

20. Berry, J.W.: Immigration, acculturation and adaptation, Applied Psychology, № 1. January. V. 46, 1997. C. 30.

\section{Information about the author:} Poliuha V. V., Ph.D. (Philosophy), Associate Professor Methods of Music Education and Conducting, Drohobych State Pedagogical Ivan Franko University 20, Sichovykh Striltsiv str., Lishnia vil., Drohobych, 82127, Ukraine 